\title{
A Case of Cushing's Disease Caused by Pituitary Adenoma Producing Adrenocorticotropic Hormone and Growth Hormone Concomitantly: Aberrant Expression of Transcription Factors NeuroD1 and Pit-1 as a Proposed Mechanism
}

Shigeyuki Tahara, M.D., Ph.D., Reiko Kurotani, Ph.D., Yudo Ishii, M.D., Naoko Sanno, M.D., Ph.D., Akira Teramoto M.D., Ph.D., R. Yoshiyuki Osamura, M.D., Ph.D.

Department of Neurosurgery (ST, YI, NS, AT), Nippon Medical School, Tokyo, Japan; and Department of Pathology (RK, YO), Tokai University School of Medicine, Boseidai, Isehara-city, Kanagawa, Japan

A 53-year-old Japanese woman was diagnosed with Cushing's disease caused by a adrenocorticotropic hormone (ACTH)-secreting pituitary adenoma on the basis of clinical an imaging data. The surgically resected tumor tissue was investigated histopathologically using immunohistochemical analysis of pituitary hormones. Our study revealed that the adenoma expressed not only ACTH but growth hormone (GH) in the tumor cells. Furthermore, immunohistochemical double staining showed that some adenoma cells were positive for both ACTH and GH. In situ hybridization for GH mRNA revealed that the adenoma cells produced GH as opposed to simply storing it. Although many pituitary adenomas produce multiple pituitary hormones, pituitary adenoma producing both ACTH and GH in the same adenoma cells, such as seen in this case, is extremely rare. To elucidate the molecular mechanism involved, we investigated the expression of transcription factors NeuroD1 and Pit-1 and found that both transcription factors were expressed in many tumor cells. This case report describes a very rare case of pituitary adenoma that produced both ACTH and GH. We propose a hitherto undescribed translineage expression of transcription factors as the basic mechanism of this unique functional differentiation.

Copyright (C) 2002 by The United States and Canadian Academy of Pathology, Inc.

VOL. 15, NO. 10, P. 1102, 2002 Printed in the U.S.A.

Date of acceptance: June 27, 2002.

Address reprint requests to: Robbert Yoshiyuki Osamura, Department of Pathology, Tokai University School of Medicine, Isehara-city, Kanagawa, 259-1193, Japan; e-mail: osamura@is.icc.u-tokai.ac.jp; fax: 81-463-91-1370.

DOI: $10.1097 / 01 . M P .0000030451 .28828 .00$
KEY WORDS: ACTH, ACTH-secreting adenoma, Cushing's disease, GH, NeuroD1, Pit-1, Pituitary, Transcription factor.

Mod Pathol 2002;15(10):1102-1105

Anterior pituitary cells are of great interest with respect to the functional differentiation of cells. Many recent reports have described various transcription factors that appear to play roles in the basic mechanisms of the production of anterior pituitary hormones. In particular, much progress has been made in the study of pituitary-specific transcription factor 1 (Pit-1), which is well known to have roles in regulating the transcription of $\mathrm{GH}$, PRL, and TSH- $\beta$ (1-9). The pituitary cell lineages in rodents have been classified into three lineages that produce POMC (ACTH), FSH-LH, or GH-PRL-TSH, depending on the expression of specific transcription factors (8). With respect to this classification, human ACTH-secreting adenomas have been reported to differ from other functioning adenomas in their early development and differentiation. We recently encountered a case of Cushing's disease caused by an ACTH-secreting pituitary adenoma that expressed ACTH and GH in the same adenoma cells. Here we report the clinical and morphological findings of this case and propose a hitherto undescribed molecular mechanism for this unique translineage functional differentiation.

\section{CASE REPORT}

A 53-year-old woman who was transferred to our hospital in 1995 was suspected of having Cushing's disease on the basis of clinical and imaging data. The patient's height and body weight were $152.7 \mathrm{~cm}$ and $54.5 \mathrm{~kg}$, respectively. The patient presented with moon face, central obesity, and pigmentation 
and atrophy of the skin. The patient also complained of muscular weakness. No neurological deficits were observed, including in the visual field. Endocrinological studies performed during the patient's first admission showed that the basal ACTH and cortisol levels were elevated to $110 \mathrm{pg} / \mathrm{mL}$ and $21.3 \mu \mathrm{g} / \mathrm{dL}$, respectively, and urinary free cortisol was also elevated to $267 \mu \mathrm{g} / \mathrm{d}$. Diurnal changes of ACTH and cortisol were not observed. In the 2-mg dexamethasone suppression test, no inhibitory effect was observed, but an inhibitory effect was observed with $8 \mathrm{mg}$ of dexamethasone. ACTH was markedly increased to $5700 \mathrm{pg} / \mathrm{mL}$ in the left-hand posterior part of the cavernous sinus (the site of an adenoma), and the central to peripheral blood ratio ( $\mathrm{C} / \mathrm{P}$ ratio) was 93.4. The intercavernous gradient, which is used to determine the localization of microadenomas, was also very prominent at 51.8. The patient's MRI at the time of admission showed a low-density mass in the left lobe of the pituitary gland with slight pituitary stalk deviation to the right (Fig. 1). The patient was diagnosed as having Cushing's disease caused by an ACTH-secreting pituitary adenoma, which was extirpated by transsphenoidal surgery. The tumor was totally resected and was soft and light yellowish-white (typical features of pituitary adenomas).

\section{PATHOLOGIC FINDINGS}

For histochemical studies, paraffin-embedded sections were used. Immunohistochemical studies for Pit-1 and Neuro D1 were carried out using the avidin-biotin-peroxidase complex method. The primary antibodies were as follows: anti-ACTH anti-

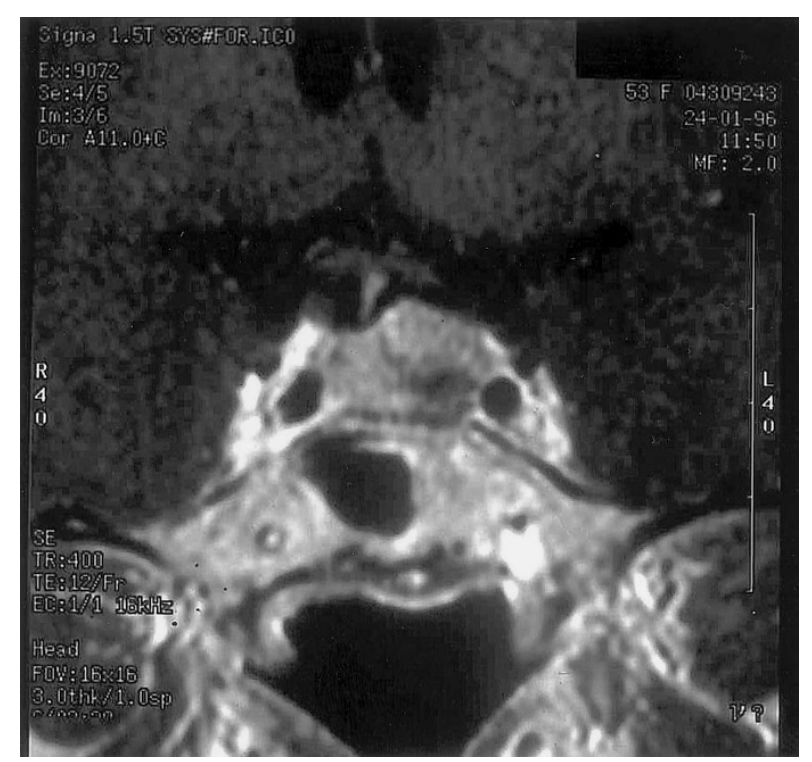

FIGURE 1. Magnetic resonance imaging showed a low-density mass in the left lobe of the pituitary gland with slight pituitary stalk deviation to the right. body (clone 02A3, 1:50; DAKO JAPAN Co., Kyoto, Japan), anti-GH antibody (1:400, DAKO JAPAN), anti-Pit-1 antibody (1:100, Santa Cruz Biotechnology, Santa Cruz, CA), anti-Neuro D1 antibody (1: 400, CeMines, Evergreen, CO). For detection of GH mRNA, in situ hybridization was performed with the following 3'-terminal biotinylated oligonucleotide probes: antisense probe 5'-GGC GCG GAG CAT AGC GTT GTC A-3', and sense probe 5'-GAC AAC GCT ATG CTC CGC GCC A-3'.

Hematoxylin-eosin (HE) staining showed that the tumor was an adenoma of diffuse type consisting mainly of basophilic cells (Fig. 2A). Immunohistochemical double staining for ACTH and GH revealed the co-localization of these two hormones in the same cells (Fig. 2B). In situ hybridization demonstrated mRNA in the cytoplasm of the tumor cells, indicating that this adenoma produced $\mathrm{GH}$ (Fig. 2, C-D). In addition, NeuroD1 and Pit-1 were expressed in the nuclei of many adenoma cells (Fig. 2, E-F).

\section{DISCUSSION}

Anterior pituitary cells can be classified into three differing lineages that produce POMC (ACTH), FSH-LH, or GH-PRL-TSH, depending on the expression of specific transcription factors. In particular, pituitary homeobox 1 (Ptxl) is known to be a universal transcription factor in all types of pituitary cells $(10,11)$ and all types of pituitary adenomas $(12,13)$. Ptxl acts synergistically with Neuro $\mathrm{D} 1 / \beta 2$, SF-1/Ad4BP, and Pit-1 to activate POMC/ ACTH, FSH-LH, and GH-PRL-TSH transcription, respectively. Multiple hormone-producing adenomas are also frequently observed among human pituitary adenomas, and such tumors usually belong to one cell lineage. It is extremely rare that a pituitary adenoma produces multiple anterior pituitary hormones of more than one lineage.

In the present case, $\mathrm{GH}$ and $\mathrm{ACTH}$, which are hormones of different lineages, were expressed in the same cells, and the presence of GH mRNA was also confirmed. These data demonstrate that GH was actually produced in ACTH-secreting adenoma cells. Furthermore, Pit-1 was expressed in the nuclei of many adenoma cells, and NeuroD1 nuclear staining was also demonstrated. These data suggest that the production of two or more hormones of more than one cell lineage may be due to aberrant patterns of expression of transcription factors in pituitary adenomas. The mechanism of how NeuroD1 and Pit-1 function synergistically is of great scientific interest but requires further investigation.

Some cases of pituitary adenomas that produce ACTH and GH simultaneously have been reported. Blevins et al. (14) reported a pituitary adenoma in a 


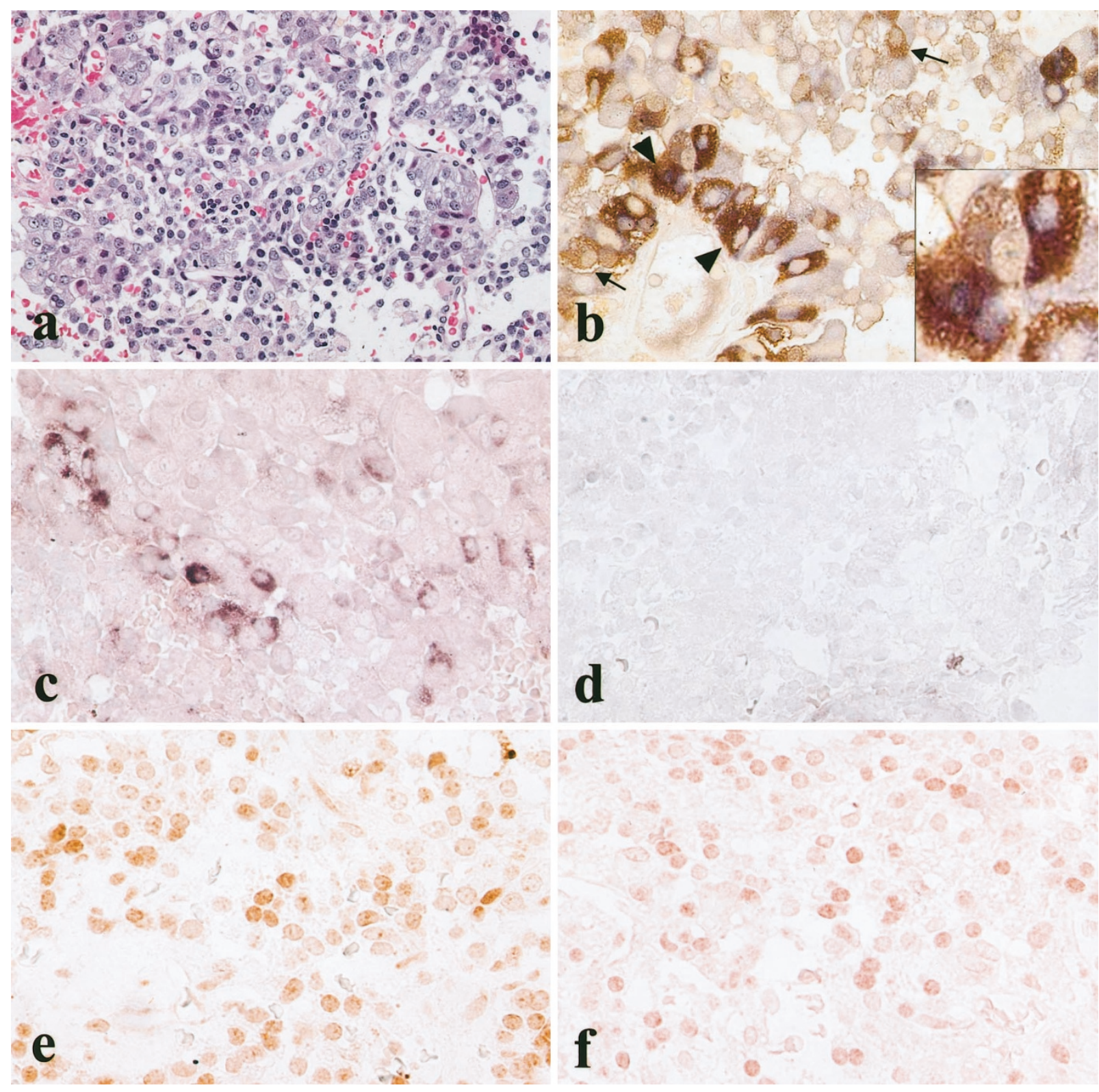

FIGURE 2. Histochemical studies. The adenoma showed basophilic cells (A). ACTH (brown) (B, arrow) and GH (blue) were detected in the adenoma by immunohistochemical double staining, and both were expressed in same adenoma cells (B, arrowhead). GH mRNA was also detected in the adenoma by in situ hybridization (C, antisense probe; D, sense probe). NeuroD1 (E) and Pit-1 (F) were expressed in the nuclei of the adenoma.

40-year-old woman with acromegaly and Cushing's disease; however, they showed by pathological examination that GH- and ACTH-producing adenomas had developed simultaneously as separate lesions. Apel et al. (15) reported a pituitary adenoma in a 76-year-old woman, and demonstrated that somatotrophs and corticotrophs existed with a clear boundary between them. On the other hand, only two cases of both ACTH and GH expression in the same adenoma tissue have been reported. Arita et al. (16) reported preoperative elevation of GH, ACTH, and cortisol which was improved by surgery, but overexpression of GH and ACTH in the adenoma cells were not noted in immunohistochemical and electron-microscopic studies. Kovacs et al.
(17) also studied a case of GH-secreting adenoma by immunohistochemistry, electron microscopy, and in situ hybridization, and reported that some ACTH was found in GH-containing granules. This is most likely the only previously reported case of the colocalization of ACTH and GH.

In conclusion, the case described here was a rare case of Cushing's disease caused by an ACTHsecreting adenoma that expressed ACTH and GH in the same adenoma cells. The finding that GH mRNA was also detected in the adenoma cells suggests that GH was not merely stored in the adenoma cells but was actually produced there. The present case is considered to be of interest with regard to research on the functional differentiation 
of pituitary adenomas. In accordance with available information about the manner of expression of transcription factors related to the pituitary, it is very rare for POMC (ACTH) and GH-PRL-TSH expression to be colocalized in the same adenoma cells, and aberrant expression of NeuroD1 and Pit-1 probably participate in this unusual differentiation state. Regarding the oncogenesis, we think the tumorgenesis occurs later than the pituitary cell development. How the aberrant expression of the transcription factors occurs is also yet to be determined.

\section{REFERENCES}

1. Bodner M, Castrillo JL, Theill LE, Deerinck T, Ellisman M, Karin M. The pituitary-specific transcription factor GHF-1 is a homeobox-containing protein. Cell 1988;55:505-18.

2. Ingraham HA, Chen RP, Mangalam HJ, Elsholtz HP, Flynn $\mathrm{SE}$, Lin CR, et al. A tissue specific transcription factor containing a homeodomain specifies a pituitary phenotype. Cell 1988;55:519-29.

3. Mangalam HJ, Albert VR, Ingraham HA, Kapiloff M, Wilson L, Nelson C, et al. A pituitary POU domain protein, Pit-1 activates both growth hormones and prolactin promoters transcriptionally. Genes Dev 1989;3:946-58.

4. Li S, Crenshaw EB, Rawson EJ, Simmons DM, Swanson LW, Rosenfeld MG. Dwarf locus mutants lacking three pituitary cell types result from mutations in the POU-domain gene Pit-1. Nature 1990;347:528-33.

5. Steinfelder HJ, Hauser P, Nakayama Y, Radovick S, McClaskey JH, Taylor T, et al. Thyrotropin-releasing hormone regulation of human TSHB expression: role of a pituitaryspecific transcription factor (Pit-1/GHF-1) and potential interaction with a thyroid hormone-inhibitory element. Proc Natl Acad Sci U S A 1991;88:3130-4.

6. Steinfelder HJ, Radovick S, Mroczynski MA, Hauser P, McClaskey JH, Weintraub BD, et al. Role of a pituitary specific transcription factor (Pit-1/GHF-1) or a closely related protein in cAMP regulation of human thyrotropin- $\beta$ subunit gene expression. J Clin Invest 1992;89:409-19.
7. Dolle P, Castrillo JL, Theill LE, Deerinck T, Ellisman M, Karin M. Expression of GHF-1 protein in mouse pituitaries correlates both temporally and spatially with the onset of growth hormone gene activity. Cell 1990;60:809-20.

8. Simmons DM, Voss JW, Ingraham HA, Holloway JM, Broide RS, Rosenfeld MG, et al. Pituitary cell phenotypes involve cell-specific Pit-1 mRNA translation and synergistic interactions with other transcription factors. Genes Dev 1990;4:695711.

9. Castrillo JL, Theill LE, Karin M. Function of the homeodomain protein GHF 1 in pituitary cell proliferation. Science 1991;253:197-9.

10. Tremblay JJ, Lanctot C, Drouin J. The pan-pituitary activator of transcription, Ptxl (pituitary homeobox 1), acts in synergy with SF-1 and Pit-1 and is an upstream regulator of the Lim-homeodomain gene Lim3/Lhx3. Mol Endocrinol 1998; $12: 428-41$

11. Kurotani R, Tahara S, Sanno N, Teramoto A, Mellon PL, Inoue $\mathrm{K}$, et al. Expression of Ptxl in the adult rat pituitary glands and pituitary cell lines: hormone-secreting cells and folliculo-stellate cells. Cell Tissue Res 1999;298:55-61.

12. Pellegrini-Bouiller I, Manrique C, Gunz G, Grino M, Zamora AJ, Figarella-Branger D, et al. Expression of the members of the Ptx family of transcription factors in human pituitary adenomas. J Clin Endocrinol Metab 1999;84:2212-20.

13. Tahara S, Kurotani R, Sanno N, Takumi I, Yoshimura S, Osamura RY, et al. Expression of pituitary homeo box 1 (Ptx1) in human non-neoplastic pituitaries and pituitary adenomas. Mod Pathol 2000;13:1097-108.

14. Blevins LS Jr, Hall GS, Madoff DH, Laws ER Jr, Wand GS. Case report: acromegaly and Cushing's disease in a patient with synchronous pituitary adenomas. Am J Med Sci 1992; 304:294-7.

15. Apel RL, Wilson RJ, Asa SL. A composite somatotrophcorticotroph pituitary adenoma. Endocr Pathol 1994;5:240-6.

16. Arita K, Uozumi T, Kuwabara S, Mukada K, Kawamoto K, Takechi A, et al. A case of pituitary adenoma producing both growth hormone $(\mathrm{GH})$ and adrenocorticotropic hormone (ACTH). Endocrinol Jpn 1991;38:271-8.

17. Kovacs K, Horvath E, Stefaneanu L, Bilbao J, Singer W, Muller PJ, et al. Pituitary adenoma producing growth hormone and adrenocorticotropin: a histological, immunocytochemical, electron microscopic, and in situ hybridization study. J Neurosurg 1998;88:1111-5. 